\title{
Innovative approaches to the formation of future specialists' professional competencies in summer educational practices course
}

\author{
Lubov Khoronko ${ }^{1,{ }^{*}}$ and Anna Mokina ${ }^{2}$ \\ ${ }^{1}$ Don state technical University, Gagarina sq., 1, Rostov-on-Don, 344003, Russia \\ ${ }^{2}$ The Southern Federal University, B. Sadovay Str., 105/42, Rostov-on-Don, 344006, Russia
}

\begin{abstract}
The article examines the issues of pedagogical science through a modern approach, the search for new forms and practices of teaching. The current issue of forming future specialists' professional competencies, namely, in the field of art and additional art education, is shown in the article through the organization of the educational environment during summer practices and schools. The task is to trace how much the effectiveness of future specialists depends on the construction of educational practice programs using interactive and interdisciplinary forms of training. As successful factors in this process of training future specialists in the field of art and additional art education, such forms as a master class and a web quest are considered, as well as the principle of a harmonious set of theoretical and practical materials used, including the process of independent work of a student. The article deals with the issue of interactive communication through a master class, which also develops the ability of professional communication of students. The use of the teacher-student dialogue in an extracurricular format, the use of interactive, multimedia and visual technologies, as well as setting tasks for independent work contributes to more effective development of professional skills and their application in the real conditions of future career guidance.
\end{abstract}

\section{Relevance of the issue}

\subsection{Introduction}

A competent approach to training specialists is one of the fundamental vectors in the modern pedagogical system of Higher Education. Each component of the educational program: Discipline, Module, and Block, form a single whole that complements and interacts with each other. In this regard, block 2 "Practices" of the educational standard is no less important than block 1 "Disciplines" and block 3 "State Final Certification". The main goal of the organization of the educational environment and the learning process is to

\footnotetext{
*Corresponding author: kenho@mail.ru
} 
reveal creative abilities, support the talents of students, identify talents and direct them to success and productivity in future professional activities.

When forming the main professional educational programs in the Higher School System, forms, goals, tasks, and teaching methods are modeled that contribute to the education of a self-sufficient professional personality ready to solve problems in future activities. The range and variability of professional competencies taken into account in the training program for future specialists affect the depth and breadth of the acquired skills and abilities of students. Another important factor affecting the student is the professionalism, demand, experience and competence of the artist-teacher. The training model, its path of construction, goals and objectives helps to educate individual and personal characteristics of future specialists, especially artistic activities, as well as timely adjustments and updating of curricula, programs, selection of necessary methods, training tools and forms.

The issue of finding new forms and methods of teaching in the field of art education is addressed by experts in different parts of the world pedagogical community: Li Q [1], Cui C. [2], Bakirlioglu Y., McMahou M. J. [3], Howard F. [4], Inwood H., Kennedy A. [5], Song M. J. [6], Puppe L., Jossberger H., Stein I., Gruber H. [7] and others. This also applies to digitalization, motivation and stimulation of students ' interest in learning, web quests, and designing in groups. In the field of design engineering published works of Aukje Thomassen, Oguzhan Ozcan [8], The search for such new forms of training that can improve the professional competence of future artists, designers and architects is also relevant in Russia. A high level of competence is the key to success and competitiveness. Today, the formation of personal qualities, properties and talents is a process managed and directed by the teacher and the heads of educational programs, including self-education and self-development of the future professional.

The block "Practices" in the main professional educational programs is an equivalent element of the educational process along with the blocks "Disciplines (modules)" and "State Final Certification". For each training area, there is a different range of educational and industrial practices: introductory, research, pedagogical, technological, art history, etc. For example, Giordano M., Trufant, L. W. [9] talked about the creation of the University of New Hampshire Faculty Instructional Technology Summer Institute (FITSI), where they consider and study the types, models and forms of innovative training during the practice period. In their turn, Yan Lo. Philip, S. W., Carroll C., Li Ta, T. Ann O. Y., Heng Tan Y., Hwee Seow [10] in their publication "Transforming educational practices: Cultural learning for short-term sojourners" share their experience in building the intensive summer field school model and S. Mujdem Vural [11] speaks about the interdisciplinary nature of higher education. Michele D. Dickey [12], Anne T. Ottenbreit-Leftwich, Thomas A. Brush, Jesse Strycker, Susie Gronseth, Tiffany Roman, Serdar Abaci, Peter van Leusen, Sungwon Shin, Wylie Easterling, and Jonathan Plucker [13] explore web quest technologies and electronic resources in education, especially for teachers. A large systematic review of learning technologies is shown in the collective work of Qian Liu, Susan Geertshuis. Rebecca Grainger [14]. In the current Russian stream of publications on the forms and structures of building summer practices, a separate direction is considered "Pedagogical practice" and various forms of summer schools for future figures in the field of education, Platonova R. I, Shkurko N. S., Lukina T. N., Sentizova M. I., Bugaeva L. P. [15]. However, this area is not well covered by the issues of conducting summer practices in the field of art education, especially if they are based on the interdisciplinary nature of tasks. 


\subsection{Purpose of the study}

The purpose of this study is to study the specifics and application in practice of the educational form of training "master class" and "web quest" technologies in the framework of summer educational practices for artists and architects, to create their own methodological development of such forms of training, to determine its significance in motivating future specialists to self - development and self-education.

Research methods: theoretical (analysis; generalization; method of analogies); empirical (study of the experience of educational organizations, normative and educational documentation; pedagogical observation).

Experimental research base: the experimental research base is the Academy of Architecture and Arts of the Southern Federal University.

\section{Masterclass and web quest in the summer practice program}

Providing high-quality professional training of graduates using innovative non-standard technologies and forms of education is one of the tasks of Higher Education teachers. The effectiveness and productivity of the learning process depends on how actively or passively the student takes a position in the process of mastering the specialty, self-development.

Educational technologies are focused on the formation of both universal, general professional and professional competencies of students. In this regard, the role and importance of summer practices, which are a continuation and basic addition to the disciplines of the professional cycle, increases. The use of such forms as a "master class" in the framework of summer schools in the educational process is an effective method of training in a short-term format.

Program of the summer school "ArHIProf" (Ar - architecture and architects, $\mathrm{H}$ - artists, I - art, Prof - professionals), organized by the teaching staff of the Academy of Architecture and Arts of the Southern Federal University: Mokina Anna Yu., Vereshchagina Evelina I., Mokina Albina Yu., was held at the «Vityaz» student camp, Divnomorskoe settlement, Krasnodar area, Russia. The main goal is to set goals and objectives for the implementation of an interdisciplinary project task for mixed-type groups that can be solved by joint efforts of artists, architects, technologists, and sociologists. Students were divided into two project groups of mixed-type bachelors, mentored by master's students of the Academy of Architecture and Arts of the Southern Federal University. The main task is to create a project for improving the camp territory, taking into account the flow and placement of campers, recreation and sports areas, creating zones and spaces for educational intensive courses, lectures and project groups, and weather conditions of the place. For mastering and rapid immersion in the task, the heads of the summer school conducted a number of master classes to master practical skills in the field of layout, organization of the environment, creation of brand books, art objects for the exterior. In the process of organizing and conducting master classes within the framework of ArHIProf, teachers invite participating students to become almost equal partners: discuss topics, materials and techniques for completing tasks at master classes, which contributes to interactive communication in the "teacher-student" format outside the classroom, tutors and students become a single level of professionals. "Partnership" cooperation during the master class is the transfer of practical project experience from the teacher to the student directly in reality, immersing in the methods and ways of work. Such master classes are also added by innovative technologies using a computer, which make it possible to raise training, almost in the "real-life" conditions, to a productively new level. During such master classes for mixed groups, where not everyone has creative and practical skills and associative and imaginative thinking, the teacher-leader must have a high level of tolerance, readiness to quickly 
respond to unexpected questions, and master new pedagogical technologies at an accelerated pace. In the process of such self-education, the teacher forms the status of himself in the profession, develops his own professional style. In the process of partner participation in the master class, students develop practical and production competencies, but also master organizational and managerial ones. The professional activity of students during the summer internship is diverse and filled with versatile functions (educational, self-developing, communicative and sociable, etc.) and relationships (with teachers, tutors, mentors, other students and the camp population), the same as the work of a professional teacher in such work.

In the process of organizing and preparing master classes within the framework of the ArHIProf summer school, teachers set several tasks that are solved during such educational events:

- work in mixed project teams;

- immersion in the "real" conditions of professional activity of an architect, artist, designer, sociologist, etc.;

- interest in the profession and immersion in new ones;

- disclosure of creative potential, regardless of the professional priorities of the participants;

- setting and solving organizational, educational, and project tasks;

- team management;

- gain new experience and knowledge;

- self-development and professional self-improvement;

- formation of communication in non-standard conditions, etc.

All the tasks were solved by both sides of a series of master classes on layout, nonwoven materials and weaving techniques for art objects in the exterior, creating a brand book, etc. (Fig. 1).

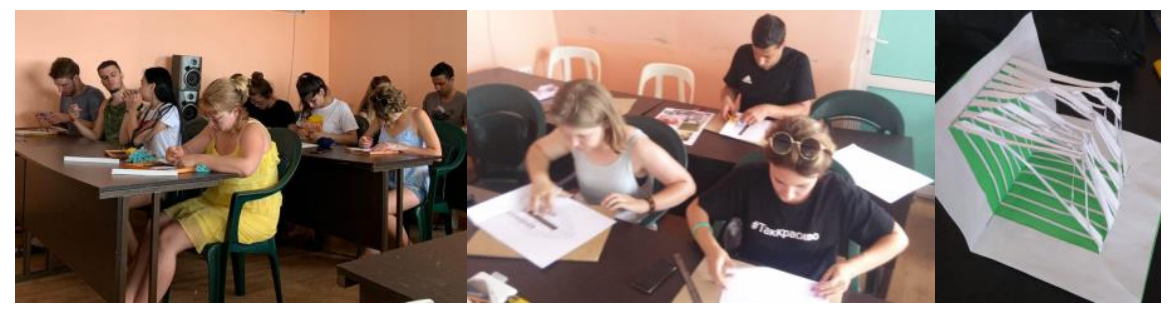

Fig. 1. Master classes on layout, non-woven materials and weaving techniques.

In the project of improvement of the camp' territory it was necessary for student groups to reflect the following aspects:

- monitor the flow of tourists and their movement around the territory in order to create a network of pedestrian and transport paths that are practically non-existent;

- conduct a survey of residents and the camp administration on what they would like to improve or create on the territory;

- to study the historical aspects of the origin and development of this camp territory;

- investigate the lighting issue;

- percentage of the coastal area use;

- whether it is necessary sports, recreation and privacy zones;

- whether it is necessary to create dominant visual points that can focus on thematic art objects.

While working on the task, the project teams also used the "web quest" form to distribute tasks among themselves, search for information and analogues of similar territories in the digital information space, and create a presentation on the material studied. 
According to Song M. J. [6] modern design and art education is impossible without the use of digital technologies at all stages, including practical activities. The integration of such technologies into the traditional artistic educational process has a positive impact on all participants: teachers, students, viewers and consumers of project activities of future architects, artists, and designers.

As a result of mastering the provided master classes and working with the web quest, students presented their author-collective projects to teachers and the administration of the camp "Vityaz". (Fig. 2). The presented works turned out to be different in terms of imagery, brand book creation, and execution techniques, but they were similar in terms of goals, conditions, and purpose of zones. As a result of a sociological survey, both teams identified a number of similar problematic issues on the territory of the camp:

- lack of good lighting in the evening and at night;

- lack of high-quality sports and recreation areas;

- small dining room space;

- the lack of audiences for educational and awareness-raising activities;

-bad noise insulation of the premises;

- not effective use of the coastal territory, etc.

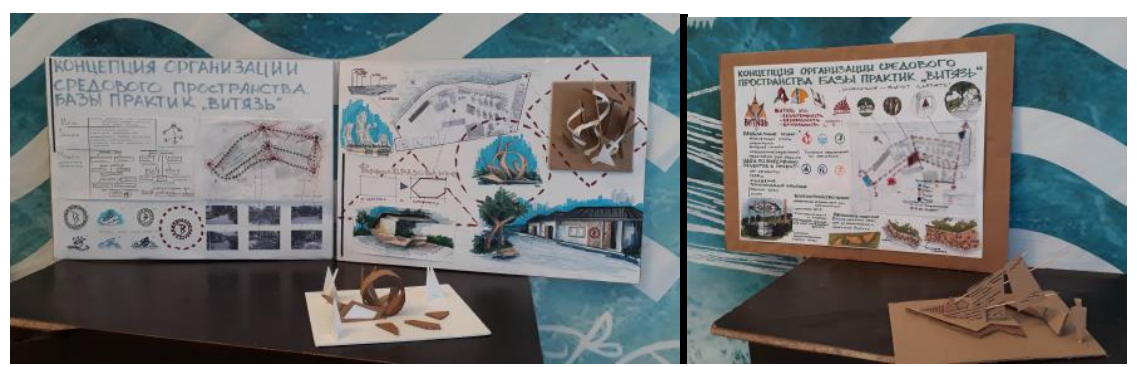

Fig. 2. The projects of students on improvement of the camp "Vityaz".

Thus, while working on a single project task, architects master and understand the importance of a sociological survey and work with applied materials, sociologists develop associative and imaginative thinking and they master practical skills of working with materials (textiles, paper, plastic materials, etc.), artists learn to apply and understand the importance of using digital and engineering design technologies in practice within the real task.

\section{Conclusions}

Modern education at High School sets the goal for the pedagogical community to search for new technologies for organizing educational, cognitive and training activities of future professional specialists. Each student in the process of studying at the University, including the period of summer internships and independent work, must gain experience in working in a team, use information and digital technologies, carrying out research and, most importantly, project activities.

The introduction of such forms of training as "master class" and "web quest" in the summer practice programs, especially in the field of art education, guarantees the success of a number of pedagogically set goals by the practice managers, the development of professional competencies for students, and most importantly, encourages motivation for deeper immersion in the chosen profession. Self-development and improvement, the desire to master the specifics of related professions, awareness of their capabilities' level in the profession, develops leadership qualities and a "good" sense of competition and challenge are also important aspects for the introduction of new training forms in the framework of 
summer practices. The level and stimulation of students' motivation in the field of art depend on the organization of an interesting educational environment, the tasks set by both teachers and students, and the personal orientations' characteristics of both sides of training in the professional sphere. Understanding their own motivations allows students to achieve success even during their undergraduate studies.

\section{References}

1. Q. Li, Advances in Intelligent Systems and Computing 1234 AISC, 646-650 (2021) DOI: 10.1007/978-3-030-51556-0_95

2. C. Cui, Advances in Intelligent Systems and Computing 1233 AISC, 431-437 (2021) DOI: 10.1007/978-3-030-51431-0_62

3. Y. Bakırlığlu, M.J. McMahou, Journal of Cleaner Production 279, 123474 (2021) DOI: $10.1016 /$ j.jclepro.2020.123474

4. F. Howard, International Journal of Art and Design Education 39(3), 672-685 (2020) DOI: $10.1111 /$ jade. 12312

5. H. Inwood, A. Kennedy, International Journal of Art and Design Education 39(3), 585599 (2020) DOI: 10.1111/jade. 12308

6. M.J. Song, International Journal of Technology and Design Education 30(4), 687-707 (2020) DOI: 10.1007/s10798-019-09524-6

7. L. Puppe, H. Jossberger, I. Stein, H. Gruber, Vocations and Learning 13(3), 389-417 (2020) DOI: 10.1007/s12186-020-09246-0

8. Aukje Thomassen, Oguzhan Ozcan, Computers \& Education 54(4), 849-855 (2010) https://doi.org/10.1016/j.compedu.2009.09.014

9. M. Giordano, L.W. Trufant, Proceedings ACM SIGUCCS User Services Conference (2002) https://www.scopus.com/inward/record.uri?eid=2-s2.00037673496\&partnerID=40\&md5=7af35d7655607fbeb469ec879cccd9d4

10. S.W. Yan Lo Philip, C. Carroll, T. Li Ta, O.Y. Ann, Y. Heng Tan, Hwee Seow, International Journal of Intercultural Relations 49, 223-234 (2015) DOI: 10.1016/j.ijintrel.2015.10.006

11. S. Mujdem Vural, Procedia - Social and Behavioral Sciences 47, 485-489 (2012) https://doi.org/10.1016/j.sbspro.2012.06.685

12. M.D. Dickey, Computers \& Education 51(2), 506-518 (2008) https://doi.org/10.1016/j.compedu.2007.05.017

13. A.T. Ottenbreit-Leftwich, T.A. Brush, J. Strycker, et al, Computers \& Education 59(2), 399-411 (2012) https://doi.org/10.1016/j.compedu.2012.01.014

14. Qian Liu, S. Geertshuis, R. Grainger, Computers \& Education 151, 103857 (2020) https://doi.org/10.1016/j.compedu.2020.103857

15. R.I. Platonova, N.S. Shkurko, T.N. Lukina, M.I. Sentizova, L.P. Bugaeva, Mathematics Education 11(7), 2515-2526 (2016) 